\title{
Non-Governmental Organizations (NGOs), Conflict and Peace Building in Nigeria
}

\author{
Anthonia O. Uzuegbunam \\ Public Administration and Local Government, University of Nigeira, Nsukka, Nigeria \\ Email: toniauzuegbunam@yahoo.com
}

Received September $5^{\text {th }}$, 2012; revised October 6 $6^{\text {th }}, 2012$; accepted October $20^{\text {th }}, 2012$

\begin{abstract}
Despite some efforts by the government, corporate bodies, civil society, national universities commission etc to reduce situations of conflict in Nigeria, peace is still elusive to her and consequently to sustainable development. This paper thus aims at an in-dept description of NGOs, conflict and peace building and proffering a way forward to reduce conflict situations through NGOs. Content analysis, was adopted, using the secondary sources of collecting data from books, journals and articles. NGOs are an aspect of civil society, without government representation, embarking in conflict reduction, welfare scheme, empowerment and employment. Among the recommendations are: government recognition and support of NGOs; NGOs increased and effective performance and government/NGOs partnership in peace and conflict issues.
\end{abstract}

Keywords: Government; Organizations; Conflict and Peace Building

\section{Introduction}

The prime value in contemporary Nigeria today is peace. It is the most valuable public good, but yet the most elusive (Francis David, 2006). The three (3) years of civil war and the recent disturbances in various parts of the country, namely the Niger Delta regions of the South-South, the Jos Bauchi Regions of Bauchi and Platue States and the Ebonyi States of the SouthEast States are at different levels of intensity and peace settlement. These have wrecked devastating effects on Nigeria in terms of considerable loss of human life, human suffering, the destruction of infrastructural facilities, the disruption of economic and agricultural activities and the coming anarchy that threatens not only the Nigeria internal peace and security but also internal peace in Africa and beyond. Alarmingly most of these areas of conflict lack the political will to maintain past peace agreements and have fallen prey to continuous armed clicks and ethnic conflict (Monty Marshal, 2003). Peace has therefore become the most pressing challenge faced by Africa at large and Nigeria in particular. This situation is partly due to unwholesome merger of multi-ethnic people by the colonial masters and partly as a result of ineffective conflict management. Despite some efforts by the government, corporate bodies, civil society, national universities commission etc to reduce situations of conflict in Nigeria, peace has continued to elude Nigeria and consequently sustainable development.

Be that as it may, this work aimed at X-raying the place of Non-Governmental Organizations (NGOs) in conflict and peace building in Nigeria and proffering a way forward to peace building in Nigeria. The work was therefore discussed under the following sections:

- Non-Governmental Organizations (NGOs);

- Conflicts in Nigeria;

- NGOs in Conflict and Peace Building in Nigeria;

- The way forward.

\section{Theoretical Base}

The theoretical approach to this study of Non Governmental Organizations (NGOs) Conflict and peace building in Nigeria is “African Theistic Humanism” propounded by Dukor, (2010). Dukor used this idea in discussing and analyzing any global issue from African philosophy or world view. African theistic humanism from philosophical perspective explains the fact that Africans originally have their own way of thinking, reacting or acting in any situation and towards any issue in life. This behavior is governed by the principle that the mother earth is always there to prescribe or proscribe for people and as such respect and compliance are required. These considerations it is believed, facilitate success, progress and solutions to problems. For instance, in Dukor's analysis of African culture and Nigeria in particular, every ethnic group has sets of values, namely moral normative and non-moral normative values. The former concerns ethical values like obligation, duty, right, wrong, desirable, undesirable, etc., while the later concerns cultural environment, poetry, agriculture unlike Islamic world with common values and law, the Africans cultural values are varied as there are variations in ethnic groups. Consequently, Dukor (2012: pp. 15-16), emphasized that African philosophy in terms of values and common law has to be placed in proper perspective. These values, Dukor referred to as "Theistic Humanism”. Further, this was summed up in a diagram with kinship at the apex, followed by extended family, communitarianism, social values, ethical values, etc. see Figure 1.

- Applying this to the analysis of Non Governmental Organizations (NGOs) Conflict and Peace Building in Nigeria, we tend to focus on what the society values. It is this thought that reveald to the analysits the nature and type of values that are existential and experienced therein. Any negation or violation of these values breeds disagreement, disorder and consequently conflict. Africans have communal 


\section{A. O. UZUEGBUNAM}

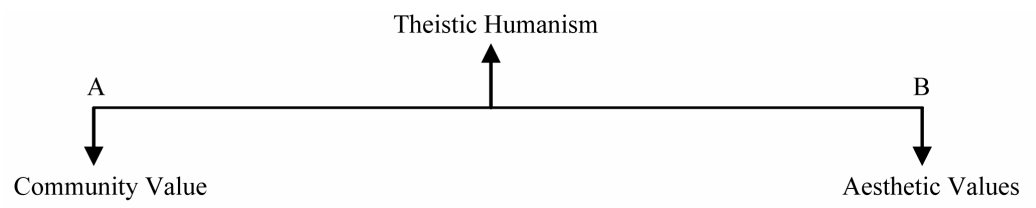

(A)

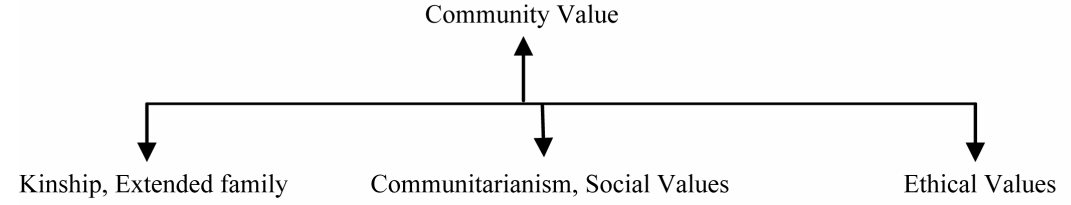

(B)

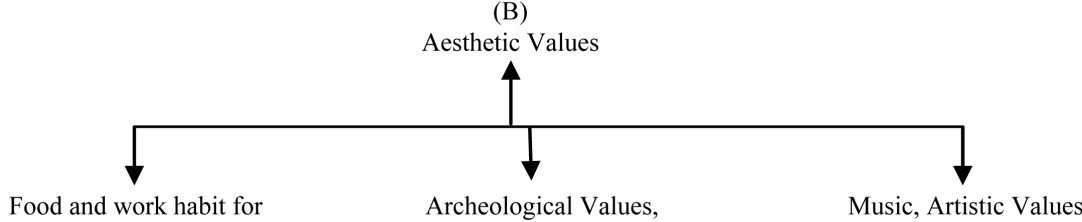

Celebration of life

Source: African Cultural Values, (Dukor, 2010:16)

Figure 1.

The African cultural values are varied as there are variations in ethnic groups. In placing African philosophy in terms of values and common law, Dukor, (2012) referred to life existence as "Theistic Humanism". This was illustrated in the above figure. The figure shows that theistic humanism gave rise to two broad groups of values namely; Community values and Aesthetical values, marked "(A)" and "(B)". From (A) — community value, we derived kinship, at the apex, extended family, communitarianism, social values and ethical values. (B) - from Aesthetic values, we derived food and work habit for celebration of life, followed by Agric and Archeological values, music and artistic values.

life, enjoy communal peace and also solve communal problems communally.

Against this back drop the analysis of NGOs Conflict and Peace Building in Nigeria was examined.

\section{Non-Governmental Organizations (NGOs)}

A Non-Governmental Organization (NGO), an aspect of civil society, is a legally constituted non-state organization created by natural or legal persons. It has no participation or representation of any government. Even in cases where NGOs are funded totally or partially by governments, they still maintain their non-governmental status by excluding government representatives from their membership. Though, NGO is legally constituted and is in general use, no legal definition is assigned to it. In many jurisdictions, NGO is defined as a civil society organization or as any other names like independent sector, social movement organization, private voluntary organization, volunteer sector, self-help organization and non-state actors, (Anheier et al., 2001).

Historically, the beginning of national NGOs started from antiquity. The international non-governmental organizations have a history dating back to at least 1839 . For instance, Rotary international was founded in 1905. It has been estimated that in 1914 there were 1083 NGOs. These international NGOs were quite helpful in the antislavery moment and at the movement for women's suffrage, which reached its peak at the time of the world disarmament conference. However, the phrase "nongovernmental organization" only came into popular use with the establishment of the United Nations Organization in 1945 with the Article 71 of chapter 10 provision made by the United Nations chapter. This is where the cumulative status of nongovernmental organization was derived. The definition of "International Non-Governmental Organization (INGO)” was first issued in resolution 288 (x) of ECOSOC on February 27, 1950. Any international organization not founded by an international treaty was then referred to as an international non-governmental organization. The vital role of NGOs and other "major groups" in sustainable development was recognized in chapter 27 of Agenda 21, that led to intense arrangements for a consultative relationship between the United Nations and Non-Governmental Organizations (NGOS), (Burton, 1997). Again, globalization of the 20th century strengthened the importance of NGOs as many problems could not be solved within nations, (Pawel Zaleski, 2006). The reason being that the international treaties and international organizations like World Trade Organization were understood as being too centered on the interests of capitalist enterprises. So in an attempt to balance this trend, NGOs developed to emphasize humanitarian issues, developmental aid and sustainable development. An outstanding example of this is the World Social Forum as a rival of World Economic Forum held annually in January at Davos, Switzerland. The 5th World Social Forum held in Porto Alegue, Brazil in January, 2005 was attended by more than 1000 NGOS representative (Abahlali, 2006). The arguments were that NGOs came as a result of welfare state restructurization in western countries. NGOs take the place of what belong to popular movements of the poor, NGOs are often imperialist, sometimes operate in a radicalized manner 


\section{A. O. UZUEGBUNAM}

in dominant countries and that they perform similar functions to that of the clergy and so on. Whatever, the case may be, NGOs transnational networking is currently extensive in many nations of the world. Consequently, Nigeria operates many (Estimate of 2000 in number) NGOs based on the different problems in the society, either as chapters of international NGOs or as local NGOs. Examples include Women in Nigeria (WIN), Women's Health Issues in Nigeria, (WHERIN) Women Aid Collective (WACOL).

Types of NGOs are discernable on the basis of their orientation and co-operation. NGO type by the level of orientation can be charitable orientation, service orientation, participation orientation and empowering orientation. NGO type by the level of co-operation are seen to be community-based, city wide based, national based and international based. Based on the above understanding, the World Bank typologised NGOs into operational and advocacy. While the operational NGOs concentrate on the design and implementation of development related projects, the advocacy NGOs focuse on defence and promotion of specific courses. Operational NGOs in Nigeria are either relief oriented or development oriented, service delivery or participatory, religious or secular, public or private oriented and community-based, national or international. Advocacy NGOs in Nigeria attempt as much as possible to raise awareness, acceptance and knowledge through lobbying, activist events and presswork.

Methods of operation of NGOs differ from organization to organization. For instance, those concerned with poverty alleviation may provide needy people with the equipment and skills to find food and clean drinking water and those concerned with human rights abuse may work through investigation and documentation of human rights violation by providing legal assistance to victims of human rights abuse. In all their endeavours, NGOs adopt public relations attitude, consulting power and project management entrepreneurship and techniques for viability and effectiveness.

Staffing of NGOs is not always issued on altruism. A few are volunteers while a good many find themselves in NGOs so as to have immediate benefits for themselves and for the people they serve especially in acquiring skills, experience finances and contacts. However the expertise of employees or volunteers may be influenced by a number of factors namely the cost of expatriate in the organization, grassroots connections, local expertise etc. The NGO sector all over the world, is an important employer in terms of numbers. For instance, the world organizations on poverty alleviation, elimination and treatment of communicable diseases, women affairs engage in employing people across the world estimating the number to the tune of $1,000,000$ as at 2007, (Stillman, 2007).

Sources of fund for NGOs include membership dues, the sales of goods and services, grants from international and national governments, private donations etc.

\section{Conflicts in Nigeria}

Discussing conflicts in Nigeria may require us to situate the clarification of the term "conflict".

"A conflict is a situation between two or more people in which one person perceives that another person has negatively affected, or is about to negatively affect”, (Holmes, 2010: p. 8). This definition contains three elements, all of which must be present in order for a conflict to exist. First, there is a specific perception on the part of one or more of the people involved in the conflict, whether the perception is accurate or inaccurate, it is held by the conflicting parties. Second, the perception is generally negative. One party believes the other is going to do something of negative effect directly or indirectly. Finally, the issue surrounding the conflict must be something both parties care about. Conflict is also seen, as a strain in a relationship that goes with emotion. The higher the emotion, the higher the tendency of an evolving conflict intensity (Aja Akpuru Aja, 2007: p. 12). Hence, to many scholars, conflict is inevitable in social life process; for conflict occurs even in the best of human societies, (Sani Shehu, 2007: p. 12). Thus, we find conflict graduating into such phases like early conflict indicators, conflict resistance, explosive or exhausitive conflict and the most deadly spiral and the highest level of violence. Again, conflict can be a frustration-based attitude or protest against lack of opportunities for development and against lack of recognition and identity. Conflict can therefore originate in class, status, ethnicity, sex, religion, nationalism or resource control, yet same fundamental issues are being addressed.

The foregoing led us to postulate that conflict has both negative and positive underpinnings. It is considered negative when it is a setback, destructive and disintegrative. Conflict is considered positive when it leads to positive developments for the individuals, the groups and the society at large through corrective signal or warning. It also leads to integrative process of development. However, change is the real subject of conflict whether in its negative or positive form. Thus, it requires the need to tailor it towards the support of existing norms and rules of social existence for if conflict of any form is left uncontrolled, the situation may be counterproductive.

Other related concepts of conflicts, include conflict indicators, conflict prevention, conflict trigger, conflict resistance, conflict explosion, conflict dynamics, conflict intervention, conflict analysis, conflict resolution, conflict management, conflict reduction, conflict stability, conflict transformation, conflict suppression and identity conflict. Conflict indicators refer to the idea that conflict is no automatic imposition. It does not just occur in any given situation. It does not happen without signs. If action is taken immediately there is any sign, the damage is prevented or limited. Conflict prevention is a process of controlling and managing strained relationship early enough to avoid the threats of a conflict. It makes effective use of early warning system to detect and respond to early threats. Conflict trigger refers to provocative utterances, decisions or actions that suddenly give rise to an outburst of frustration or aggression through open violence. This is most often associated with armed conflict, mass murder, genocide against defenceless or unsuspected civilians. Thus, hardly do we have automatic violence without a particular trigger on the moment of aggression.

Conflict resistance connotes a protracted conflict situation that has long been endured. In Nigeria and African societies, many cases of conflict resistance abound. Conflict explosion means heightened level of violence. This kind of conflict situation fails to observe the sacredness of life liberty and property and as such extreme use of arms of demonize and dehumanize human nature. Example of this conflict explosion is terrorism where people are involved in engaging in killing, destroying their targets and dying for their faith. Such actions include rampant suicide bombing in the Middle East, Iran, Iraq, Syria, Isreal and Lebanon. Terrorism and its activities are frequently experienced in advanced countries of Britain and USA, Sep- 
tember 11, 2001 terrorist attacks on the USA has remained the highest display of conflict explosion. Terrorism activities also exist in African countries leadership like Abacha Obasanjo and Yar Adua extreme violence in Nigeria, Mobutu in Zarie, Mugabe in Zimbabwe, Idi Amini in Uganda and recent Sudanese and Syria leadership. Conflict dynamics is in form of conflict analysis using the factors like history of the relationship, the primary and secondary actors, the structures (factional goals, attitudes and behaviour), the intensity (low, moderate or extreme), strategies adopted by conflicting parties, pattern of regime responses and facilitators of conflict transformers.

Conflict resolution is the process of systematizing intelligence and strategies on "dos" and "don'ts". So as to enhance their capacity building in favour of bargaining, negotiation, mediation, conciliation and arbitration, (Miall et al., 1999: p. 2). Conflict resolution is to help parties develop common, norms, rules and regulations on utterance, attitudes, actions and hopes to give peace a chance. No readymade "conflict resolution for any conflict case. It differs from conflict case to another. Conflict management refers to the open and clear dialogue in assisting opponents to develop agreement against hostile images or actions, but compliance to agreed resolution and strategies. Conflict management operates as a drive from conflict resolution. Conflict management is where the two parties concerned share the same ideas, principles in their capacity to make peace reign. The third party involvement can be from states or "regimes” multilateral actors initiatives and non-governmental organization initiative. Conflict stability is also known as crisis stability which means a condition whereby each party perceives parity in an overall balance of military power. It tends to serve as deterrence that helps to restore peace.

Conflict transformation refers to the state of new situation involving conflict issues, perceptions, relationships and communication patterns. It is a change initiated by a third party for readjusting the emotional, perceptual and spiritual approaches to a conflict situation. Conflict suppression of a sub-concept of conflict transformation, positive oriented that enables interveners to work hard in the direction of positive change.

Conflict identity refers to the environment of the individuals involved in the conflict. e.g., Ethnic identities, kinship groups necessary for development of out-groups and in groups. This is the issue that breeds the "us' and "them" syndrome. In multilinguistic societies like Nigeria. Ethnic problems emerge as a result of competition of the following:

- control of state power;

- different development plans;

- educational controversies;

- resources control struggles;

- religions intolerance;

- land disputes;

- indigene-settle syndrome (migration and compete conquest).

These differences in issues become entangled in themselves and cause ethno-national to manage or resolve. This penetrates the very fabric of society and engenders living misunderstanding among groups within nations.

\section{Examples of Cases of Conflicts in Nigeria}

Cases of conflict situations abound in Nigeria right from precolonial period till date. Examples of these conflicts include the following among others:
- Nigeria-Biafra Civil War (1967-1970);

- The Inter-Communal Conflicts like Zango-Kataf Crisis (1992);

- Ife-Modakeke political and religion crises (pre-colonial to date);

- Aguleri-Umuleri conflicts (since 1933);

- Religious conflicts in Kano State;

- Religious conflicts in Kaduna State;

- Social and Political Motivated Federal Election Crises of 1964;

- National Census Controversy of 1962;

- Western Nigeria Election Crises of 1965;

- Niger Delta crises in Ogoni, Ijaw and Warri.

However, apart from political and military issues mentioned above, potential causes of conflicts in Nigeria have increased and diversified to a large extent. These causes include recruiting ground for international terrorist networks, organized crime, drug traffickers, new tensions created by refugees across borders and state failure to cater for the citizens and those in special needs.

\section{The Concept of Peace Building}

Peace building is the identification and support of measures needed for transformation toward more sustainable, peaceful relationship and structures of governance, so as to avoid a relapse into conflict, (UN, 2007). Peace building is also perceived as attempts to conquer the structural, relational and cultural contradictions hastily causing conflict, especially in strong support of peace making and peacekeeping. Inspirations of peace building are drawn from developmental imperatives facing mankind and conflict resolution initiatives, (Ifesinachi, 2009). Again efforts of peace building may be imported from outside the system thereby overlooking the structures and cultures of the parties concerned. The approach to the efforts of peace building could be bottom-top and or top-bottom. Whichever base the efforts are directed to, the end results must be in respect, promotion and use of local human and socio-cultural resources. Peace building has assumed such a prominent position in the minds of the international community members and all peace lovers in the world. Hence the call for every one to contribute in making peace a reality. Thus, the United Nations (UN) security council installed peace building as its number 2 point agreement under the provision of chapter VI of the UN charter.

\section{The Role of NGOs in Conflict and Peace Building in Nigeria}

It is an understatement to state that the aim or purpose of peace building is to prevent conflict and create peace. A suggestion was made that peace has two different concepts-negative peace and positive peace. Negative peace refers to mere absence of violence, but positive peace is said to be a stable social equilibrium in which the surfacing of new disputes cannot escalate into violence and war (Henning, 1998). The emphasis on finding and resolving the root causes of conflict is criticized on the grounds that it is an overtly negative view of social conflict. Conflict may contribute to a dynamic and innovative society once it is not violence. Since it is increasingly acknowledged that social conflict is inevitable, some approaches to peace building have shifted the emphasis from the 
root causes of social conflict to good governance and peaceful settlement of dispute mechanisms.

In conflict resolution, NGOs embark on problem solving workshops and seminars aimed at internal conflicts like the religious crises in Kano and Kaduna states, Bauchi and Plateau States, Enugu-Ezike crises in Enugu State where especially the women groups had series of meetings resulting in the following:

1) Deciding to engage in dialogue to resolve mutually intolerable problems;

2) Coming together to map the elements of the problems and the relationship that perpetuate the problems;

3) Uncovering the underlying dynamic of the relationships and beginning to see ways to change them;

4) Planning steps together to change the relationships and;

5) Devising ways to implement their plan.

Indeed what conflict resolution offers is more than enough theoretical and practical ways of developing peace in conflict environments. These can be exploited at several levels so as to channel global, regional and national norms of interdependence, human security and democratization into unstable local environments. It is therefore in, this situation that NGOs contribution to the process of conflict resolution is very critical. NGOs play the role of facilitating a linkage between global, regional and organization, thereby resolving one of the most serious problems of the conflict resolution genre related to the trickleup and down effect of conflict, (Henning, 1998). This is because NGOs conduct humanitarian, developmental, human rights, and conflict resolution activities that enhance the process of peace making.

NGOs place in peace-building in society cannot be over emphasized. The inadequacies of first generation approaches to conflict resolution both nationally and globally has called for settlements to be based upon just political orders that promote democracy and human rights, new norms, participatory governance structures, civil society, international tribunals and truth commissions. Thus, under the auspices of the United Nation (UN), disarming, repatriating refugees, building a consensus for peace and moderate local political leadership appear to be important issues in building peace. Since this is based on conflict resolution and perspectives of conflict, it requires deep access into local environments and grassroots processes rather than top-down approaches. Thus NGOs can always provide these conditions as a result of their official and human security oriented base.

\section{Conclusion}

Non-Governmental Organizations (NGOs) are doing even more peace building activities than any official governmental agencies. In many of the areas of the world at large and in Nigeria in particular, they have a long term presence that are afflicted with intractable conflicts. NGOs are in an excellent position to engage in a wide variety of peace building activities. Added to the process of providing humanitarian aid and mediation, they are also well positioned to engage in empowerment and capacity building among the local population in getting them involved with the adversary in a variety of joint activities. In accordance with official government peace building efforts, the goal NGO efforts is usually conflict reduction and/or resolution, not just between official actors but also among ordinary citizen.
Again, much peace building efforts especially peace church members like Christian union, Christian women group try to foster reconciliation through apology, prayer and forgiveness. Some other organizations work for mutual understanding and prejudiced reduction. This is pursued through development of joint projects and confidence building activities involving opponents, at the grassroots level. Even though their projects and strategies vary, they all encourage increased contact and cooperation between people on all sides of the conflict.

Conflict and peace building exist in literature. Nonetheless, most opinions accepted that conflict involves disagreement, frictions, and misunderstanding, violent and non-violent, in the course of relationship with others or with innerself. Peace building actions to create and sustain peace results in all its ramifications are also available.

\section{The Way Forward}

As a way for improvement of the performance of NGOs in conflict and peace building in Nigeria, the following are recommended.

- NGOs should recognize that peace building is a political undertaking rather than a development and humanitarian one;

- Funding of NGOs from the local government should be increased for effective performance of their responsibilities;

- Since the importance of NGOs in conflict resolution and peace building has been recognized by the international community, the Nigeria government should also recognize NGOs important contributions towards the grassroots involvement in peace building and accord them same;

- The NGOs should recognize the different phases of conflict and ensure that each phase is effectively aligned with their peace building activities;

- NGOs should embark on going into the communities to teach them non violent conflict resolution;

- The NGOs members should be committed to the activities for peace building and be honest in discharging their responsibilities;

- An integrated effort of NGOs with other civil organizations requires effective partnership to yield better activities and aggregate for a significant impact;

- Nigerians should recognize the importance of NGOs in conflict resolutions and peace building in societies, and therefore undertake researches on the activities of NGOs in Nigeria for significant documentation.

\section{REFERENCES}

Abahlali, B. M. (2006). Rethinking public participation from below, "critical dialogue".

http://en.wikipedia.org/wiki/non-governmental_organization

Anheier et al. (1997). The rise and fall of transnational civil society: The evolution of international non-governmental organizations since 1839. http://abahlali.org/node

Anheier et al. (2001). The new geography of global civil society: NGOs in the world city network. Journal of International Globalization, 1 265-277.

Anheier et al. (2007). What is an NGO? New York. Cambridge University Press.

Azar, E. (1990). The management of protracted social conflict. Theory and cases, Dartmounth: Aldershot.

Burton, J. (1990). Conflict resolution and prevention. New York: St. 


\section{A. O. UZUEGBUNAM}

Martins Press.

Burton, J. (1997). Violence experienced: The source of conflict violence and crime and their prevention. New York: Manchester University Press.

Charnovitz (1992). Agenda 21-Chapter 27: Strengthening the role of non-governmental organizations: Partners for sustainable development, Earth Summit.

Charnovitz (1997). Two centuries of participation: NGOs and international governance. Michigan Journal of International Law, 18, 281282

Charnovitz (2005). Subcontracting peace-The challenges of NGO peace building. Farnham: Ashgate.

Charnovitz (2007). Charter of the United Naitons: Chapter X.

Coupleston, F. A. (2005). A history of philosophy, Vol. 6, Modern philosophy, The enlightenment voltaire to kant. London: Conduim.

DFAIT (1996). DFAT/NGO peace building consultation. Canada: Department of Foreign Affairs and International Trade.

Dukor, M. (2010). African philosophy in the global village: Theistic pan psychic axiology and science. Saarbrücken: Lap Lambert Academic Publishing Gamb \& Co.

Federal Republic of Nigeria (1995). Report of the constitution containing the resolution and recommendations (Vol. 2). Abuja: National Aseembly Press.

Galtung, J. (1996). Peace by peaceful means: Peace and conflict, development and civilization (pp. 1-3). London: Sage.
Lyal, S. S. (2007). “Dilemmas facing INGOs in coalition-occupied Iraq", in ethics in action: The ethical challenges of international human rights non-governmental organizations. Cambridge: Cambridge University and United Nations University Press.

Monty, G. M., \& Ted, G. (2003). Peace and conflict. A global survey of armed conflicts, self determination movement and democracy. College Park: University of Maryland.

Osagae, E. (1991). Ethnic minorities and federalism in Nigeria. African Affairs, 90, 237-258.

Pawel Zaleski Global (2006). Non-governmental administrative system: Geosociology of the third sector. Warszawa: IFIS Publishers.

Pawel Zaleski Global (2007). World bank criteria defining NGO. http://parltrack.euwiki.org/mep/PawelZALEWSKI

Shedrack, G. B. (2007). The method of conflict resolution and transformation. Ibadan: Ibadan Spectrum Book Ltd.

Teegen, H., Doh, J., \& Vachani, S., (2004). The importance of nongovernmental organization in global governance and value creation: An international business research agenda. Journal of International Business Studies, 35, 463-483. doi:10.1057/palgrave.jibs.8400112

UN (1992). An agenda for peace: Preventive diplomacy, peace making and peace keeping. Report of the Secretary-General, United Nations GA and SC, A/47/277, S/24111.

UN (1995). DAC, guidelines on conflict, peace and development cooperation. Paris: OECD. 